Bangl. J. Vet. Med. (2006). 4 (2): 97-101

\title{
PERFORMANCE OF BROILER FED WITH DIFFERENT COMMERCIAL COMPOUND FEEDS OF
} BANGLADESH

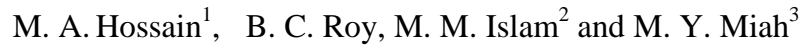 \\ Department of Poultry Science, Faculty of Animal Husbandry, Bangladesh Agricultural University, \\ Mymensingh-2202, Bangladesh
}

\begin{abstract}
An attempt was made to investigate the responses of broiler to feed the compound feeds of different feed mills located in Bangladesh. Keeping this view in mind, a total of 260 of star-bro broiler chicks were fed on compound diets in the age duration of day old to 38 days to compare the performance of broilers of different dietary groups. All the forms of feed were of identical (pellet feed) as well as same management and environment were provided for all the treatments. The body weight gain was highest in $\mathrm{T}_{2}$ dietary group $(\mathrm{P}<0.01)$ which was statistically similar with $\mathrm{T}_{1}$ group. Feed intake of the 5 treatments differed significantly $(\mathrm{P}<0.01)$. $\mathrm{T}_{1}$ dietary group showed high trend of feed consumption. Higher FCR value $(\mathrm{P}<0.01)$ was observed for $T_{5}$ dietary group which indicated low feed conversion efficiency. On the other hand, $T_{2}$ and $T_{1}$ dietary groups showed better feed conversion efficiency. Survivability percent of all treatments was not differed significantly (P $>0.05$ ). Significant differences were obtained for meat yield parameters such as body weight, blood loss, shank weight, liver weight, abdominal fat, dressed carcass and edible carcass weight. On the other hand, non significant differences were obtained for feather loss, gizzard weight, spleen weight, heart weight, head weight. Except the body weight $(\mathrm{P}<0.01)$ no significant results were observed for sex(s) as well as interaction between treatment and sex effect for all other meat yield parameters. The results of this experiment from biological responses of birds gave an impression that compound feeds of the feed mills $T_{1}$, $T_{2}$ and $T_{3}$ were found to be better than those feeds of $T_{4}$ and $T_{5}$ feed mills for the production of commercial broiler for the age duration of day old to 38 days of age.
\end{abstract}

Key words: Compound feeds (pellet), broiler, feed mills, performance

\section{INTRODUCTION}

Poultry meat and eggs contribute approximately 33\% of total animal protein supplied in the country (Ahmed and Islam, 1990). Farm produced meat and eggs are gaining popularity throughout the country. Hossain (1999) estimated that farm produced broilers, spent hens and cockerels constitute $55 \%$ of the total chicken and farm produced eggs $82 \%$ of the total eggs marketed in Dhaka city. According to FAO statistics, Bangladesh produced 104000 tones hen eggs and 111000 tones chicken meat giving her world position of 46 and 52 respectively in 1998. The latest information available from Poultry International (Anon., 2000) also showed that per capita poultry meat and egg consumption is around $1 \mathrm{~kg}$ and 20 eggs/respectively. This data clearly indicate that the availability of poultry meat and egg is still very much lower in Bangladesh in spite of the significant development in the commercial sector during the last 10 years.

The exact number of feed mills now in operation is not definitely known but a report stated that there are 40 feed mills with 900 dealers at the private sector who are producing and distributing poultry feeds all over the country (Latif, 1999). Although a good number of feed mills are in operation in the country only a few of these are serious in maintaining quality of their product. A report stated that, the feed requirement is about 1610 thousand metric tones per year, of which 472 thousand metric tones (i.e. 29.34\%) is covered by industrial feed and the remaining 1138 thousand metric tones are replenished by the feeds from other sources (i.e., self-mixed feed) of the poultry farm (Source: Bangladesh Poultry Industries Associations cited by Khan and Husain, 2002).

Present address : ${ }^{1}$ Department of Dairy \& Poultry Science, ${ }^{2}$ Department of General Animal Science \& Animal Nutrition, Chittagong Veterinary and Animal Sciences University, Khulshi, Chittagong; ${ }^{3}$ Department of Dairy \& Poultry Science, Sylhet Agricultural University, Tilagor, Sylhet. 
There is reason to believe that the feed manufactured by different feed mills used to nourish the all poultry farms existing in Bangladesh may or may not meet the standard with respect to quality. It is known that optimum productivity of a farm depends on the quality feed supplied to birds. If bad quality feeds are supplied to the birds it may adversely affect the production of the farm. Again higher quality feeds dramatically improve the productivity of the farm. In view of the availability and source of different feed ingredients, the level of nutrients in the prepared ration may vary from what is actually desired. Deficiency of a particular nutrients in the ration may not be overruled which is generally unnoticed by the farm owners causing an undesirable effect on production. In view of above situation, the present study was undertaken with the following objectives to investigate the performance of broilers in terms of body weight gain, feed intake, feed efficiency, survivability, meat yield by feeding of different compound feeds.

\section{MATERIALS AND METHODS}

A total of 260 day-old Starbro strait-run broiler chickens purchased from 'Biman Poultry Complex', Savar, Dhaka, were randomly divided into five treatment groups $\left(T_{1}, T_{2}, T_{3}, T_{4} \& T_{5}\right.$ having 52 chickens in each treatment group. Each treatment had four replications of 13 birds. The chickens were reared for 38 days at Bangladesh Agricultural University Poultry Farm, Mymensingh, during the period from 1st October 2002 to $10^{\text {th }}$ November 2002. Different commercial compound feeds were supplied to the chickens of different treatment groups ad libitum as below (Table 1).

Table 1. Feeding of different commercial compound feeds to different treatment groups

\begin{tabular}{|ll|}
\hline Treatment groups* & Feed manufacturer \\
\hline $\mathrm{T}_{1}$ & Aftab Bahumukhi Farm Lmited \\
& Koliachar, Bazitpur, Kishoregonj \\
$\mathrm{T}_{2}$ & Quality Feed Limited \\
& Shirirchala, Bagher Bazar, Gazipur \\
$\mathrm{T}_{3}$ & Nourish Poultry Feed Limited \\
& Gusinga, Sreepur, Gazipur \\
$\mathrm{T}_{4}$ & Fresh Feeds Limited \\
& Meghnaghat, Sonargaon, Narayangonj \\
$\mathrm{T}_{5}$ & Sundarban Feeds Limited \\
& Ambug, Zampur, Madanpur, Sonargaon, Narayangonj \\
\hline
\end{tabular}

*Chickens of different treatment groups were provided with starter diet for first three weeks, grower diet for next two weeks and then finisher diet till the end of the experiment. Fresh drinking water was supplied three times a day to the chickens of all the groups.

Body weight gain, amount of feed intake, feed conversion ratio, survivability and meat yield parameters were recorded for each replication. To record the meat yield traits the chickens were taken in the Department of Poultry Science, Bangladesh Agricultural University, Mymensingh and were dissected following the standard procedure. All dead birds were sent to the Pathology laboratory, Department of Pathology, Bangladesh Agricultural University, Mymensingh for post-mortem examination to identify the causes of death.

\section{Statistical analysis}

All recorded and calculated data were statistically analyzed for analysis of variance in a Completely Randomized Design (CRD) using a SAS statistical Computer package program. Significant differences between means were identified by Least Significance Differences (LSD). An analysis of variances was performed on the collected data to identify the performances of the birds feeding on the compound feeds of five feed mills. Significant differences between means were identified by Least Significant Differences (LSD). 
Performance of broiler fed with compound feeds

\section{RESULTS AND DISCUSSION}

The results obtained through biological trial of feeds are presented under the following heads (Table 2).

Table 2. Responses of broiler chicks to feeds of different feed mills

\begin{tabular}{|c|c|c|c|c|c|c|c|}
\hline \multirow[t]{2}{*}{ Parameters } & \multirow{2}{*}{$\begin{array}{l}\text { Age } \\
\text { (Days) }\end{array}$} & \multicolumn{5}{|c|}{ Treatments } & \multirow{2}{*}{$\begin{array}{l}\text { Level of } \\
\text { Significance }\end{array}$} \\
\hline & & $\begin{array}{l}\text { Aftab } \\
\text { Feed }\left(\mathrm{T}_{1}\right)\end{array}$ & $\begin{array}{l}\text { Quality } \\
\text { Feed }\left(\mathrm{T}_{2}\right)\end{array}$ & $\begin{array}{l}\text { Nourish } \\
\text { Feed }\left(\mathrm{T}_{3}\right)\end{array}$ & $\begin{array}{l}\text { Fresh } \\
\text { Feed }\left(\mathrm{T}_{4}\right)\end{array}$ & $\begin{array}{l}\text { Sundarban } \\
\text { Feed }\left(\mathrm{T}_{5}\right)\end{array}$ & \\
\hline \multirow{6}{*}{$\begin{array}{l}\text { Live weight } \\
\text { Gain } \\
\text { (g/broiler) }\end{array}$} & $1-21$ & 637.33 & 733.82 .9 & 708.7 & 714.4 & 686.9 & \multirow[t]{2}{*}{ NS } \\
\hline & & \pm 18.34 & \pm 12.0 & \pm 23.85 & \pm 25.03 & \pm 51.84 & \\
\hline & $22-35$ & 896.92 & 890.25 & 881.81 & 829.62 & 882.69 & \multirow[t]{2}{*}{ NS } \\
\hline & \multirow{3}{*}{$1-38$} & & \pm 14.73 & \pm 56.18 & \pm 31.61 & \pm 33.06 & \\
\hline & & $2049.87^{\mathrm{a}}$ & $2071.41^{\mathrm{a}}$ & $1995.46^{\mathrm{ab}}$ & $1927.43^{\mathrm{bc}}$ & $1889.6^{\mathrm{c}}$ & \multirow[t]{2}{*}{$* *$} \\
\hline & & \pm 38.2 & \pm 91.87 & \pm 32.3 & \pm 63.38 & \pm 94.68 & \\
\hline \multirow{6}{*}{$\begin{array}{l}\text { Feed } \\
\text { consumption } \\
\text { (g/broiler) }\end{array}$} & $1-21$ & 1062.1 & 1059.64 & 1053.6 & 1040.67 & 1045.7 & \multirow[t]{2}{*}{ NS } \\
\hline & & \pm 4.52 & \pm 12.57 & \pm 16.9 & \pm 10.86 & \pm 14.92 & \\
\hline & $22-35$ & 1771.49 & 1794.88 & 1774.14 & 1782.83 & 1780.34 & \multirow[t]{2}{*}{ NS } \\
\hline & & \pm 8.85 & \pm 9.36 & \pm 21.66 & \pm 15.51 & \pm 17.68 & \\
\hline & \multirow[t]{2}{*}{$1-38$} & $3987.07^{\mathrm{a}}$ & $3983.05^{\mathrm{a}}$ & $3912.95 .4^{\mathrm{b}}$ & $3821.75^{c}$ & $3812.0^{c}$ & \multirow[t]{2}{*}{$* *$} \\
\hline & & \pm 7.83 & \pm 4.79 & \pm 69.17 & \pm 42.14 & \pm 47.70 & \\
\hline \multirow{3}{*}{$\begin{array}{l}\text { Feed } \\
\text { conversion } \\
\text { ratio }\end{array}$} & $1-21$ & $1.52 \pm 0.03$ & $1.44 \pm 0.04$ & $1.49 \pm 0.06$ & $1.46 \pm 0.04$ & $1.53 \pm 0.10$ & \multirow{3}{*}{$\begin{array}{l}\text { NS } \\
* \\
\text { NS }\end{array}$} \\
\hline & $22-35$ & $1.97^{\mathrm{b}} \pm 0.03$ & $2.02^{\mathrm{b}} \pm 0.03$ & $2.02^{\mathrm{b}} \pm 0.16$ & $2.15^{\mathrm{a}} \pm 0.08$ & $2.02^{\mathrm{b}} \pm 0.06$ & \\
\hline & $1-38$ & $1.95 \pm 0.04$ & $1.96 \pm 0.10$ & $1.96 \pm 0.022$ & $1.98 \pm 0.08$ & $2.02 \pm 0.09$ & \\
\hline \multirow{3}{*}{$\begin{array}{l}\text { Survivability } \\
(\%)\end{array}$} & $1-21$ & $100 \pm 0$ & $100 \pm 0$ & $98.4 \pm 3.44$ & $98.4 \pm 3.44$ & $98.4 \pm 3.44$ & NS \\
\hline & $22-35$ & $98.07 \pm 4.55$ & $98.4 \pm 3.44$ & $98.4 \pm 3.44$ & $98.4 \pm 3.44$ & $100 \pm 0$ & NS \\
\hline & $1-38$ & $98.07 \pm 4.5$ & $98.07 \pm 3.44$ & $96.15 \pm 4.21$ & $96.15 \pm 4.21$ & $98.07 \pm 3.44$ & NS \\
\hline
\end{tabular}

${ }^{*} \mathrm{P}<0.05 ; * * \mathrm{P}<0.01 ; \mathrm{NS}=$ Non-significant, Means bearing uncommon superscripts in a row differ significantly.

\section{Body weight gain}

During 1-38 days of age the highest body weight gain (2071.41g/broiler) was found in $\mathrm{T}_{2}$ (Quality feed) group, which was statistically similar to $T_{1}$ and $T_{3}$ dietary groups. The lowest body weight gain was occurred in $T_{5}$ group which was significantly different $(\mathrm{P}<0.05)$ from the remaining groups except $\mathrm{T}_{4}$. The results coincided with the report of Mitchell et al. (1972) and Sinha et al. (1994).

\section{Feed intake}

Statistically similar but significantly highest $(\mathrm{P}<0.01)$ feed intake of birds was observed in $\mathrm{T}_{1}$ and $\mathrm{T}_{2}$ groups. On the other hand, significantly lowest $(\mathrm{P}<0.01)$ feed consumption was found in $\mathrm{T}_{5}$ group which was statistically similar to $\mathrm{T}_{4}$ group.

\section{Feed conversion ratio}

At the end of the experiment (1-38), the highest FCR value (2.02) was observed in $\mathrm{T}_{5}$ dietary group and the lowest FCR value (1.95) was observed in $T_{1}$ (Table 2). The highest feed conversion ratio was observed in $T_{5}$ then $T_{4}, T_{3}, T_{2}$ and $T_{1}$ subsequently. It is noteworthy that, birds having higher feed conversion ratio values generally regarded as poorer in performance than those which have lower feed conversion ratios or vice versa. 


\section{Survivability}

Only three birds from $T_{1}, T_{2}$ and $T_{5}$ dietary groups died during the trial period from 1-38 days of age resulting in 98.07 percent survivability. The survivability of each of the other dietary groups was 96.15 percent. The result of the birds survivability lead to a non-significant difference. The results were coincided with the findings of Kamar et al. (1974) who reported that compound (pellet) feed fed birds showed less mortality than other types of feed at all ages. But disagreed with the report of Barbosa and Campos (1994) who showed that mortality was higher in pellet feeds and males were more susceptible than female.

\section{Meat yield parameter}

Significant differences were obtained for body weight, blood loss, heart weight, abdominal fat, edible carcass weight, dressing percentage. On the other hand, non-significant differences were observed for feather loss, liver weight, shank weight, head weight, gizzard weight, and spleen weight. These findings agreed with the report of Howlider and Rose (1992) who observed that total meat yield as proportion of body weight was not altered by sex or diet (Table 3).

Table 3. Meat yield traits of different dietary treatments and interaction of sex and diet on meat yield of broiler

\begin{tabular}{|c|c|c|c|c|c|c|c|c|c|c|}
\hline \multirow[t]{3}{*}{ Parameter } & \multirow[t]{3}{*}{ Sex } & \multicolumn{5}{|c|}{ Different dietary treatments } & \multirow[t]{3}{*}{ Mean } & \multirow{2}{*}{\multicolumn{3}{|c|}{$\begin{array}{l}\text { LSD values and } \\
\text { level of } \\
\text { significance }\end{array}$}} \\
\hline & & \multirow[t]{2}{*}{$\mathrm{T}_{1}(\mathrm{~A})$} & \multirow[t]{2}{*}{$\mathrm{T}_{2}(\mathrm{Q})$} & \multirow[t]{2}{*}{$\mathrm{T}_{3}(\mathrm{~N})$} & \multirow[t]{2}{*}{$\mathrm{T}_{4}(\mathrm{~F})$} & \multirow[t]{2}{*}{$\mathrm{T}_{5}(\mathrm{~S})$} & & & & \\
\hline & & & & & & & & $\mathrm{T}$ & $\mathrm{S}$ & $\mathrm{T} \times \mathrm{S}$ \\
\hline \multirow{4}{*}{$\begin{array}{l}\text { Body weight } \\
\text { (g/bird) }\end{array}$} & $\mathrm{M}$ & 1800 & 1860 & 1780 & 1775 & 1750 & 1793.05 & & & \\
\hline & $\mathrm{F}$ & 1775 & 1790 & 1750 & 1700 & 1730.25 & 1749.09 & & & \\
\hline & Mean & $1787.5^{\mathrm{ab}}$ & $1825^{\mathrm{a}}$ & $1765^{\mathrm{b}}$ & $1737^{\mathrm{b}}$ & $1740^{\mathrm{b}}$ & & $* *$ & $* *$ & * \\
\hline & & \pm 22.1 & \pm 44 & \pm 25.1 & \pm 51.2 & \pm 12.4 & & & & \\
\hline \multirow{3}{*}{$\begin{array}{l}\text { Blood loss } \\
(\%)\end{array}$} & $\mathrm{M}$ & 6.60 & 6.4 & 6.89 & 7.4 & 5.7 & 6.5 & & & \\
\hline & $\mathrm{F}$ & 6.04 & 6.2 & 6.95 & 6.0 & 6.1 & 6.25 & & & \\
\hline & Mean & $6.34^{\mathrm{b}} \pm 0.36$ & $6.3^{\mathrm{b}} \pm 0.43$ & $6.9^{\mathrm{a}} \pm 0.11$ & $6.7^{\mathrm{a}} \pm 0.70$ & $5.9^{\mathrm{c}} \pm 0.14$ & & $* *$ & NS & NS \\
\hline & M & 6.3 & 6.5 & 6.2 & 6.23 & 6.6 & 6.34 & & & \\
\hline \multirow{2}{*}{ (\%) } & $\mathrm{F}$ & 6.06 & 6.2 & 7.0 & 6.37 & 6.34 & 6.05 & & & \\
\hline & Mean & $6.1 \pm 0.14$ & $6.3 \pm 0.11$ & $6.6 \pm 0.21$ & $6.3 \pm 0.22$ & $6.5 \pm 0.08$ & & NS & NS & NS \\
\hline Shank weight & M & 4.33 & 4.6 & 4.09 & 4.64 & 3.85 & 4.52 & & & \\
\hline \multirow{2}{*}{ (\%) } & $\mathrm{F}$ & 4.24 & 4.3 & 4.31 & 4.29 & 4.15 & 4.13 & & & \\
\hline & Mean & $4.2 \pm 0.04$ & $4.4 \pm 0.21$ & $4.2 \pm 0.46$ & $4.4 \pm 0.19$ & $4.0 \pm 0.34$ & & NS & NS & NS \\
\hline Head weight & M & 4.0 & 4.2 & 3.57 & 3.86 & 3.03 & 3.70 & & & \\
\hline \multirow{2}{*}{ (\%) } & $\mathrm{F}$ & 3.64 & 3.7 & 4.0 & 3.34 & 3.35 & 3.65 & & & \\
\hline & Mean & $3.8 \pm 0.23$ & $3.9 \pm 0.29$ & $3.7 \pm 0.23$ & $3.6 \pm 0.12$ & $3.1 \pm 0.16$ & & NS & NS & NS \\
\hline Liver weight & $\mathrm{M}$ & 2.0 & 2.2 & 2.14 & 2.5 & 1.86 & 2.14 & & & \\
\hline \multirow[t]{2}{*}{ (\%) } & $\mathrm{F}$ & 2.31 & 2.15 & 2.42 & 2.3 & 1.94 & 2.47 & & & \\
\hline & Mean & $2.1 \pm 0.21$ & $2.17 \pm 0.12$ & $2.4 \pm 0.44$ & $2.4 \pm 0.09$ & $1.9 \pm 0.19$ & & NS & NS & NS \\
\hline Gizzard weight & $\mathrm{M}$ & 2.12 & 2.3 & 2.14 & 2.14 & 1.94 & 2.07 & & & \\
\hline \multirow[t]{2}{*}{$(\%)$} & $\mathrm{F}$ & 2.1 & 2.15 & 2.07 & 2.07 & 2.5 & 2.21 & & & \\
\hline & Mean & $2.1 \pm 0.08$ & $2.2 \pm 0.12$ & $2.0 \pm 0.11$ & $2.1 \pm 0.11$ & $2.0 \pm 0.10$ & & NS & NS & NS \\
\hline \multirow{3}{*}{$\begin{array}{l}\text { Spleen weight } \\
(\%)\end{array}$} & $\mathrm{M}$ & 0.27 & 0.29 & 0.22 & 0.21 & 0.29 & 0.25 & & & \\
\hline & $\mathrm{F}$ & 0.24 & 0.25 & 0.21 & 0.23 & 0.28 & 0.24 & & & \\
\hline & Mean & $0.25 \pm 0.04$ & $0.27 \pm 0.04$ & $0.21 \pm 0.02$ & $0.22 \pm 0.02$ & $0.28 \pm 0.05$ & & NS & NS & NS \\
\hline \multirow{3}{*}{$\begin{array}{l}\text { Abdominal fat } \\
\text { weight (\%) }\end{array}$} & $\mathrm{M}$ & 1.3 & 1.34 & 1.2 & 1.18 & 1.25 & 1.28 & & & \\
\hline & $\mathrm{F}$ & 1.46 & 1.44 & 1.3 & 1.22 & 1.37 & 1.34 & & & \\
\hline & Mean & $1.38^{\mathrm{a}} \pm 0.06$ & $1.3^{\mathrm{a}} \pm 0.09$ & $1.25^{\mathrm{bc}} \pm 0.03$ & $1.20^{\mathrm{C}} \pm 0.11$ & $1.31^{\mathrm{b}} \pm 0.09$ & & $* *$ & NS & NS \\
\hline \multirow{3}{*}{$\begin{array}{l}\text { Dressed weight } \\
\text { (\%) }\end{array}$} & $\mathrm{M}$ & 72.59 & 74.07 & 72.0 & 70.4 & 69.5 & 69.21 & & & \\
\hline & $\mathrm{F}$ & 69.01 & 68.73 & 69.0 & 68.24 & 67.95 & 67.2 & & & \\
\hline & Mean & $70.8^{\mathrm{a}} \pm 1$ & $71.4^{\mathrm{a}} \pm 0.99$ & $70.55^{\mathrm{ab}} \pm 1$ & $69.3^{\mathrm{b}} \pm 1$ & $68.73^{\mathrm{C}} \pm 0.36$ & & * & NS & NS \\
\hline \multirow{4}{*}{$\begin{array}{l}\text { Edible carcass } \\
\text { weight (\%) }\end{array}$} & $\mathrm{M}$ & 84.70 & 84.54 & 85.65 & 84.05 & 81.21 & 81.21 & & & \\
\hline & $\mathrm{F}$ & 83.39 & 83.99 & 83.13 & 83.29 & 80.9 & 80.91 & & & \\
\hline & Mean & $84.0^{\mathrm{a}}$ & $84.2^{\mathrm{a}}$ & $84.3^{\mathrm{a}}$ & $83.67^{\mathrm{b}}$ & $81.6^{\mathrm{b}}$ & $81.06^{c}$ & $*$ & NS & NS \\
\hline & & $\pm 1.15^{\mathrm{a}}$ & \pm 0.62 & \pm 0.66 & \pm 0.07 & \pm 0.5 & & & & \\
\hline
\end{tabular}

Values bearing different superscript in a row differ significantly, NS $=$ Non significant, $* *=p<0.01, *=p<0.05$. 
Performance of broiler fed with compound feeds

\section{REFERENCES}

1. Ahmed S and Islam I (1990). Backyard poultry development project in 100 villages proceeding of the $1^{\text {st }}$ conferences of Bangladesh Animal Husbandry Association, Dhaka, Bangladesh. pp. 133-138.

2. Anon. (2000). Poultry International. August 2000, P 10.

3. Barbosa MJB and Campos EJ (1994). Incidence of ascites according to the levels of metabolizable energy (ME) and physical form of feeds in sexed broilers. Poultry Abstract 20: 309.

4. FAO (1998). The output of meat \& egg of Bangladesh. Food out look, No. 4, Rome, Italy.

5. Hossain SA (1999). Marketing of egg and broiler in Bangladesh. Proceeding of the $2^{\text {nd }}$ International Poultry Show and Seminar, 1999, Worlds’ Poultry Science Association, Bangladesh-Branch. pp. 59-69.

6. Howlider MAR and Rose SP (1992). The response of growing male and female broiler chickens kept at different temperatures to dietary energy concentration and feed from. Animal Feed Science and Technology 39:71-78.

7. Kamar GAR, Akheireldin MA, El-Difran AF and Ghany MA (1974). A comparison between pelleted and mash feeding for growing chicks. Egyptian Journal of Animal Production 14: 129-135.

8. Khan MM and Husain BH (2002). Macroeconomic (supply and demand situation) analysis of poultry sub-sector. Khamar. pp. 9-12; 15.

9. Latif M (1999). History of Poultry Industry in Bangladesh. Proceeding of the $2^{\text {nd }}$ International Poultry Show and Seminar. WPSA Bangladesh-Branch. pp. 11-17.

10. Mitcheel RJ Waldroup PW, Hillard CM and Hazen KR (1972). Effects of pelleting and practical size on utilization on roasted soybeans by broilers. Poultry Science 51: 509-510.

11. Sinha SC, Digvijal S and Pandita NN (1994). Effect of feeding grower mash ration on the performance of broilers. Poultry Today \& Tomorrow 4: 26-30. 